R. K. PRINJHA*, M.A. DAWSON* ET AL. (GLAXOSMITHKLINE MEDICINES RESEARCH CENTRE, STEVENAGE, UK; PETER MACCALLUM CANCER CENTRE, MELBOURNE, AND UNIVERSITY OF MELBOURNE, AUSTRALIA)

Selective Targeting of BD1 and BD2 of the BET Proteins in Cancer and Immunoinflammation

Science 2020, 368, 387-394.

\section{Selectively Binding a Bromodomain}

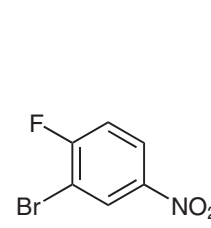

1. $\mathrm{NaH}, \mathrm{BnOH}$

2. 3,5-dimethylisoxazol-4-yl)boronic acid PEPPSI-IPr, $\mathrm{Cs}_{2} \mathrm{CO}_{3}$

3. $\mathrm{Fe}, \mathrm{NH}_{4} \mathrm{Cl}$

4. diethyl 2-(ethoxymethylene)malonate $46 \%$ yield
over 4 steps over 4 steps
$S_{N} A r$, Suzuki coupling

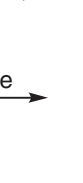<smiles>CCOC(=O)C(=CNc1ccc(OCc2ccccc2)c(-c2c(C)noc2C)c1)OCC</smiles>

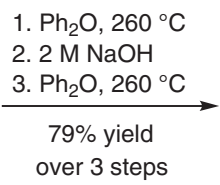

1. $\mathrm{HNO}_{3}, \mathrm{EtCO}_{2} \mathrm{H}$

2. $\mathrm{POCl}_{3}$<smiles>Cc1noc(C)c1-c1cc2[nH]ccc(=O)c2cc1OCc1ccccc1</smiles>

3. $(R)$ - $\alpha$-methylbenzylamine, DIPEA 4. $\mathrm{Fe}, \mathrm{AcOH}$

$45 \%$ yield
over 4 steps
$S_{N} A r$<smiles>Cc1noc(C)c1-c1cc2ncc(N)c(N[C@H](C)c3ccccc3)c2cc1OCc1ccccc1</smiles>

1. 2-methoxyacetyl chloride, pyridine 2. $\mathrm{EtCO}_{2} \mathrm{H}$

3. $\mathrm{H}_{2}, \mathrm{Pd} / \mathrm{C}$

4. A, $\mathrm{K}_{2} \mathrm{CO}_{3}$

5. $4 \mathrm{M} \mathrm{HCl}, 1,4$-dioxane

$30 \%$ yield over 5 steps
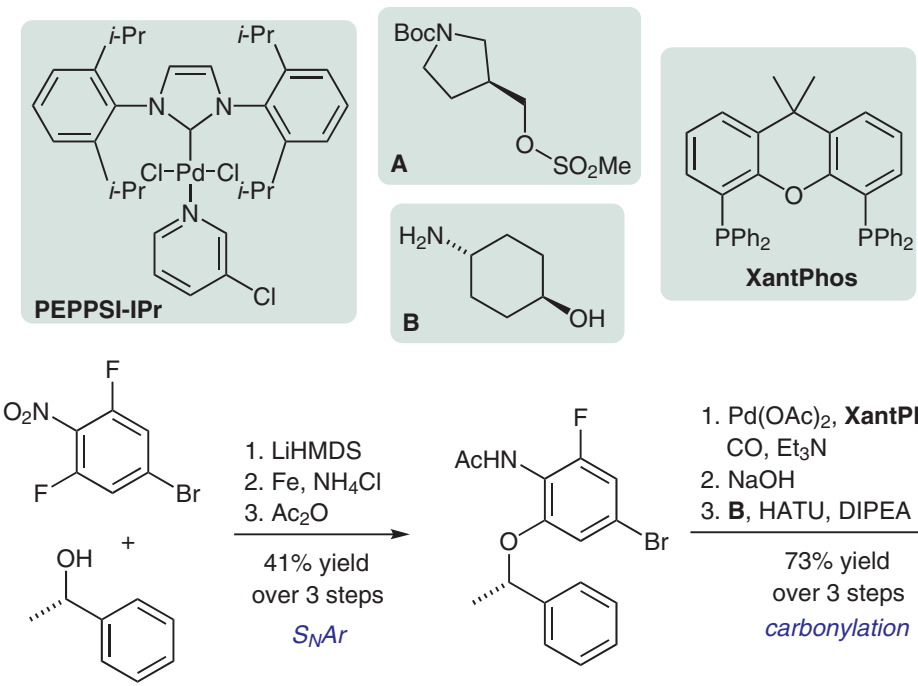

1. $\mathrm{Pd}(\mathrm{OAc})_{2}$, XantPhos, $\mathrm{CO}, \mathrm{Et}_{3} \mathrm{~N}$

2. $\mathrm{NaOH}$

3. B, HATU, DIPEA

$73 \%$ yield

over 3 steps

carbonylation

Category

Chemistry in

Medicine and

Biology

Key words

BET inhibitors

bromodomain

epigenetics

BRD4

cancer

Significance: The BET (bromo- and extraterminal) family of proteins are epigenetic readers, modulate gene expression, and are attractive anticancer targets. The human BET proteins contain two highly homologous bromodomains, BD1 and BD2, equally bound by classical inhibitors. Selective inhibitors enable studies on the individual functions of BD1 and BD2.
Comment: Prinjha, Dawson, and co-workers developed very selective inhibitors for BD1 (iBET-BD1) and BD2 (iBET-BD2), complementing recently developed ABBV-744 (Nature 2020, 578, 306). They show that BD1 inhibition replicates the effect of pan-BET inhibitors in cancer models, whereas BD2 inhibition is more effective in models of immunoinflammation. 